\title{
A BOULDER OF OUACHITITE FROM INDERSKÄR, ÅLAND ISLANDS, FINLAND
}

\author{
P. KRESTEN and Nils Edelman
}

\begin{abstract}
Kresten, P. and Edelman,Nils 1975: A boulder of Ouachitite from Inderskär, Åland Islands, Finland. Bull. Geol. Soc. Finland 47, 167-169.

The ouachitite is composed of phenocrysts of olivine, diopside, phlogopite, set in a fine-grained matrix with phlogopite, clinopyroxene, ore and calcite. Analyses of the rock and of several minerals are given. It is concluded that the boulder most likely originates from an alkaline complex, genetically and geographically related to the Alnö complex in central Sweden.
\end{abstract}

P. Kresten, Department of Mineralogy, Petrology and Geochemistry, University of Stockbolm, S-113 86 Stockbolm, Sweden.

Nils Edelman, Abo Akademi, 20500 Abo 50, Finland.

This paper is a more detailed investigation of a boulder found at Söderören, Inderskär, $3 \mathrm{~km}$ W of Enklinge, Aland islands, SW Finland, previously described by Edelman (1974). The boulder was $10 \times 8 \times 3 \mathrm{~cm}$ in size, subrounded, with mica phenocrysts in a brownish grey matrix.

In thin section, phenocrysts of olivine, often completely altered into serpentine, phlogopite, diopsidic pyroxene and rarely, magnetite and apatite, are found. The matrix is composed of fine-grained phlogopite and clinopyroxene, with abundant ore and calcite. The mode is given in Table 1. From its composition, the rock might most aptly be termed ouachitite (Tröger 1935, p. 176). The chemical composition of the ouachitite shows somewhat lower contents of silica and alumina than the type rock.

Phlogopite is light brown in thin section. Pheno- crysts often show bleached, groundmass phlogopite darkened margins, which is probably explained by varying titanium contents. Reversed pleochroism has been observed in groundmass phlogopite. The chemical analysis (1, Table 2) shows rather high titanium contents; the $\mathrm{Mg}$ / $(\mathrm{Mg}+\mathrm{Fe})$ ratio is 0.79 , which is within the limits for phlogopite.

Olivine is rather abundant as a phenocrystal phase (mode, Table 1), but completely absent in the matrix. As mentioned earlier (Edelman 1974), many phenocrysts are completely altered into pale green serpentine. In sections made for this study, fresh olivine was found and analysed (2-3, Table 2). Both rounded and euhedral phenocrysts occur; The latter seem much more altered than the former.

Clinopyroxene occurs both as phenocrysts 
Table 1.

Chemical composition, norm and mode of the ouachitite

\begin{tabular}{|c|c|c|c|c|c|}
\hline $\mathrm{SiO}_{2}$. & 30.4 & Norn & & Mode $(0.33 \times 0.40 \mathrm{~mm}$ & grid, \\
\hline $\mathrm{TiO}_{2}$. & 2.9 & $\mathrm{Ne}$ & 2.19 & 3811 points counted) & \\
\hline $\mathrm{Al}_{2} \mathrm{O}_{3}$ & 8.6 & An & 11.50 & Phenocrysts & \\
\hline $\mathrm{Fe}_{2} \mathrm{O}_{3}$ & 7.9 & $\mathrm{Cc}$ & 9.58 & Olivine $\ldots . .$. & 2. \\
\hline $\mathrm{FeO} \ldots$ & 6.3 & Ap & 4.45 & Serpent. olivine .. & \\
\hline $\mathrm{MnO}$. & 0.28 & $\mathrm{Ft}$ & 1.79 & Phlogopite ..... & \\
\hline $\mathrm{MgO}$. & 13.7 & Mt & 7.89 & Diopside ...... & \\
\hline $\mathrm{CaO}$. & 15.8 & Il . & 4.10 & Magnetite ...... & \\
\hline $\mathrm{BaO}$. & 0.35 & Py & 1.80 & Apatite ... & \\
\hline $\mathrm{Na}_{2} \mathrm{O}$ & 0.4 & Wo & 8.47 & Matrix & \\
\hline $\mathrm{K}_{2} \mathrm{O}$. & 3.5 & Di & 4.86 & Phlogopite ..... & \\
\hline $\mathrm{H}_{2}^{2} \mathrm{O}-$ & 0.7 & $\mathrm{Ol}$ & 8.62 & Clinopyroxene.... & \\
\hline $\mathrm{H}_{2} \mathrm{O}+$ & 2.6 & $\mathrm{Bi}$ & 33.60 & Ore $\ldots \ldots \ldots \ldots$ & \\
\hline $\mathrm{P}_{2} \mathrm{O}_{5}$. & 2.10 & & & Apatite . & \\
\hline $\mathrm{CO}_{2} \ldots$ & 3.85 & & & Calcite..$\ldots \ldots \ldots$ & \\
\hline S $\ldots$. & 0.68 & & & Remainder $\ldots \ldots$ & \\
\hline & 0.40 & & & & \\
\hline $\mathrm{Cl}$. & 0.01 & & & & \\
\hline
\end{tabular}

Total . 100.47

O corr. -0.34

Sum . 100.13

Table 2.

Mineral analyses (electron microprobe, Geol. Surv. of Sweden)

\begin{tabular}{lrrrrrrr} 
& \multicolumn{1}{c}{1} & \multicolumn{1}{c}{2} & \multicolumn{1}{c}{3} & \multicolumn{1}{c}{4} & 5 & 6 & 7 \\
$\mathrm{SiO}_{2}$ & 36.6 & 39.5 & 39.5 & 49.0 & 47.8 & - & - \\
$\mathrm{TiO}_{2}$ & 4.8 & - & - & 1.3 & 1.2 & 5.8 & 6.6 \\
$\mathrm{Al}_{2} \mathrm{O}_{3}$ & 17.4 & 0.1 & 0.0 & 4.6 & 4.4 & - & - \\
$\mathrm{Fe}_{2} \mathrm{O}_{3}$ & - & - & - & - & - & $\left.53.2^{*}\right)$ & $\left.54.7^{*}\right)$ \\
$\mathrm{FeO} .$. & 9.3 & 14.0 & 13.0 & 6.5 & 6.5 & $\left.35.9^{*}\right)$ & $\left.35.1^{*}\right)$ \\
$\mathrm{MnO} \cdot$ & 0.1 & - & - & 0.2 & 0.2 & - & - \\
$\mathrm{MgO} \cdot$ & 18.2 & 47.0 & 46.3 & 14.8 & 14.2 & - & - \\
$\mathrm{CaO}$ & - & 0.3 & 0.3 & 23.3 & 23.4 & - & - \\
$\mathrm{Na} \mathrm{O}_{2} \mathrm{O}$ & - & - & - & 0.7 & 0.7 & - & - \\
$\mathrm{K}_{2} \mathrm{O}$ & 9.7 & - & - & 0.0 & 0.0 & - & - \\
\cline { 2 - 8 } & 96.1 & 100.9 & 99.1 & 100.4 & 98.4 & 94.9 & 96.4
\end{tabular}

\begin{tabular}{|c|c|c|c|c|c|}
\hline $\mathrm{Nr} 0$ & 22 & 4 & 4 & 6 & 6 \\
\hline $\mathrm{Si}^{4}+\ldots$ & 5.282 & 0.980 & 0.991 & 1.821 & 1.820 \\
\hline $\mathrm{Al}^{3}+$ & 2.718 & 0.003 & - & 0.179 & 0.180 \\
\hline $\mathrm{Al}^{3}+$ & 0.248 & - & - & 0.021 & 0.016 \\
\hline $\mathrm{Ti}^{4}+$ & 0.526 & - & - & 0.036 & 0.035 \\
\hline $\mathrm{Fe}^{2+}$ & 1.121 & 0.290 & 0.274 & 0.202 & 0.204 \\
\hline $\mathrm{Mn}^{2}+$ & 0.002 & - & - & 0.006 & 0.005 \\
\hline $\mathrm{Mg}^{2}+$ & 3.912 & 1.736 & 1.734 & 0.822 & 0.806 \\
\hline $\mathrm{Ca}^{2}+\ldots$ & - & 0.008 & 0.008 & 0.929 & 0.954 \\
\hline $\mathrm{Na}^{+} \ldots$ & - & - & - & 0.049 & 0.048 \\
\hline $\mathrm{K}+\ldots$ & 1.784 & - & - & - & - \\
\hline $\mathrm{Mg}$ & 0.79 & 0.86 & 0.86 & 0.80 & 0.79 \\
\hline
\end{tabular}

*) Calculated from total $\mathrm{FeO}$

1. Phlogopite, phenocryst.

2. \& 3. Olivine, phenocrysts.

4. Clinopyroxene, monomineralic cluster.

5. 》 , phenocryst.

6. Titaniferous magnetite, large phenocryst.

7. " , , from matrix. (single grains, or monomineralic clusters) and as a major constituent of the matrix. Phenocrystal pyroxene is colourless to pale brown in thin section, weakly pleochroic, and sometimes weakly zoned (darkened margins). Two analyses (45, Table 2) proved the pyroxene to be diopside, with rather high titanium contents. Frequently, fluid inclusions, occupying arcuate planes (healed cracks) are encountered. The inclusions are very similar to those described for kimberlite pyroxenes (Mitchell et al. 1973) as well as for pyroxenes from the Alnö complex (v. Eckermann 1966). Matrix clinopyroxenes are more strongly coloured and, according to semi-quantitative analyses, richer in both iron and titanium than phenocrystal clinopyroxenes.

Magnetite occurs rarely as phenocrysts, but is quite abundant in the matrix (mode, Table 1). Both forms contain about $6 \% \mathrm{TiO}_{2}$, and may properly be termed titanomagnetite (Table 2). No exsolution lamellae have been noted. Matrix pyroxene is a common inclusion in magnetite; pyrite is sometimes found to form coatings around magnetite grains.

Apatite occurs both as larger $(0.5-1 \mathrm{~mm})$ short-prismatic grains, and tiny acicular crystals in the matrix. Pyrite forms coatings on magnetite, and irregular (almost vermicular) masses associated with interstitial calcite. Calcite is found both as an interstitial phase, in cracks in phenocrysts, and together with serpentine, chlorite and other phases replacing primary minerals.

Cblorite (clinochlore) has been found to replace phlogopite. Occasionally, greyish felt-like masses with low birefrigence occur, which could not be identified. They always occur together with serpentine and calcite, and are thus alteration products. Very rarely, small brownish cubes are seen, sometimes forming clusters. The mineral might be perovskite rather than garnet, as suggested earlier (Edelman 1974).

As pointed out by Edelman (1974), two possible places of origin of the boulder exist: either the boulder has been transported from the Alnö alkaline complex, situated about 300 
$\mathrm{km}$ WNW of Inderskär, or the boulder may derive from some alkaline complex north of Aland, the existence of which is at present unknown. The chemical composition of the Aland ouachitite does not differ greatly from the composition of alnöitic, ouachititic and kimberlitic dikes in the Alnö complex (v. Eckermann 1948, 1958). The high titanium and barium contents, in particular, agree with the data for Alnö rocks. The mineralogical composition of the Aland ouachitite differs from the composition of the Alnö alkaline dykes encountered so far in one important point: diopside has not been recorded as a constituent of the Alnö dikes. Instead augite, aegirine-augite, titaniferous augenite and pigeonitic pyroxene have been recorded (v. Eckermann 1948, 1958, 1966, 1974). Also, the ouachitites at Alnö contain major amounts of melanite, which is absent from the Aland specimen.

Very recently, a large nodule of diopside was discovered by one of us (P. K.) in the alnöitic breccia at Hovid ( $c f$. v. Eckermann 1948, p. 100).
This seems to be the first record of diopside within the Alnö complex. This diopside is, however, rather different in chemical composition to the ones occurring as phenocrysts in the Aland rock, and probably represents upper mantle material (Kresten \& Persson 1975).

Summarizing the evidence, it may be stated that rocks comparable to the Aland ouachitite are not known to occur in the Alnö alkaline complex. Because of the great similarity between the ouachitite and the Alnö rocks, we suggest that the boulder originates from a subsidiary intrusion, related to the main Alnö intrusion both geographically and genetically. It might be situated east or southeast of Alnö, covered by the Gulf of Bothnia.

Acknowledgements. - All analytical work has been carried out by the Swedish Geological Survey and Mr. Christopher Grapes, BA. checked the language; this is gratefully acknowledged.

\section{REFERENCES}

Eckermann, H. v. (1948) The alkaline district of Alnö Islands. Sveriges Geol. Unders. Ca, 36. 176 p.

- (1958) The alkaline and carbonatitic dykes of the Alnö formation on the mainland north-west of Alnö Island. Kungl. Svenska Vetenskapsakad. Handl. IV, 7 (2). $61 \mathrm{p}$.

- (1966) The pyroxenes of the Alnö carbonatite (sövite) and the surrounding fenites. Min. Soc. India, IMA vol: $126-139$.

- (1974) The chemistry and the optical properties of some minerals of the Alnö alkaline rocks. Arkiv Min. Geol. 5 (8): $93-210$.

Edelman, N. (1974) Kimberlitblock från Åland. Geologi 26 (3): 28.
Kresten, P. and Persson, L. (1975) Discrete diopside in alnöite from Alnö Island. Lithos (in press).

Mitchell, R. H., Carswell, D. A. and Brunfelt, A. (1973) Mineralogy and rear earth geochemistry of any ilmenite-clinopyroxene xenolith from Monaster Mine. Pp. 224-229 in Lesotho Kimberlites, ed. by P. H. Niüon. LNDC, Maseru, Lesotho.

Tröger, W. E. (1935) Spezielle Petrographie der Eruptivgesteine. Verlag der Deutsch. Mineral. Ges. 360 p.

Manuscript received, March 6, 1975. 